\title{
Changes in muscle fiber populations and muscle enzyme activities in the primiparous lactating sow
}

\author{
L Lefaucheur \\ with the technical assistance of $P$ Ecolan \\ INRA, Station de Recherches Porcines, INRA, St Gilles, 35590 L'Hermitage, France
}

(Received 9 January 1990; accepted 23 May 1990)

\begin{abstract}
Summary - An experiment involving 12 primiparous Large White sows was conducted to investigate changes in contractile and metabolic characteristics of skeletal muscle during the first 3 weeks of lactation. The sows lost $19.7 \pm 6.6 \mathrm{~kg}$ of body weight. No change in DNA concentration was observed in the longissimus dorsi (LD), a fast-twitch glycolytic muscle, and the trapezius (T), a mainly slow-twitch oxidative muscle during lactation. The percentage of type I fibers increased $(P<0.05)$ in LD, but not in T. The muscle fiber cross sectional area (CSA) of IIB fibers, which represents about $78 \%$ of the total number of LD fibers, decreased by $18 \%(P<0.01)$ by lactation; the CSAs of I and IIA fibers were not significantly affected. Marker enzyme activities for oxidative and glycolytic metabolisms decreased in both muscles during lactation. The decrease in oxidative enzyme activities was particularly dramatic in T $(P<0.001)$. No significant relationship was observed between sow weight loss and changes in muscle fiber CSA or enzyme activities. The extent to which the results could be related to a negative nutritional balance or to changes in hormonal status is discussed.
\end{abstract}

swine / lactation / skeletal muscle / muscle fiber / metabolism

Résumé - Modifications des types de fibres et des activités enzymatiques du muscle chez la truie primipare en lactation. Une expérience portant sur 12 truies primipares de race Large White a été réalisée afin d'étudier les modifications de certaines caractéristiques contractiles et métaboliques du muscle squelettique pendant les 3 premières semaines de lactation. Les truies ont perdu $19,7 \pm 6,6 \mathrm{~kg}$ de poids vif. Aucune modification de la concentration en ADN des muscles longissimus (LD) (un muscle à contraction rapide et métabolisme glycolytique) et trapézius (T), (un muscle essentiellement à contraction lente et métabolisme oxydatif) n'a été observée. Le pourcentage de fibres de type I n'a augmenté que dans le $L D(P<0,05)$. L'aire de section transversale (AST) des fibres $\| B$, qui représentent $78 \%$ environ du nombre total de fibres du muscle $L D$, a diminué de $18 \%$ ( $P<0,01)$ pendant la lactation; I'AST des fibres I et llA n'a pas été significativement modifiée. Les activités d'enzymes marqueurs des métabolismes oxydatif et glycolytique ont diminué dans les 2 muscles au cours de la lactation. La décroissance du métabolisme oxydatif a été particulièrement importante dans le muscle $T(P<0,001)$. Aucune relation n'a été observée entre la perte de poids vif des truies et la réduction de l'AST des fibres du LD ou des activités enzymatiques. La possibilité d'interpréter les résultats en fonction de la balance nutritionnelle des animaux ou de leur état hormonal est discutée. 


\section{INTRODUCTION}

More attention has been paid to the adequacy of muscle metabolism in relation to growth or to under-nutrition than in relation to lactation. However, the sow is under extensive nutritional stress during early lactation, particularly when feed intake does not meet the nutrient requirement for milk production and maintenance. During the first weeks post-partum, tissue catabolism results in loss of body fat (Whittemore et al, 1980), negative nitrogen balance (Elsley and MacPherson, 1972) and loss of muscle tissue (Etienne et al, 1985). The latter authors showed that primiparous sows lost about $10 \mathrm{~kg}$ of muscle during the first 3 weeks of lactation, whatever their energetic level ( 14.2 or $10.3 \mathrm{Mcal} \mathrm{ME} / \mathrm{d}$ ). Muscle weight loss during lactation is now well known, but, to our knowledge, very little attention has been paid to the possible alteration of tissular metabolism particularly skeletal muscle during lactation in the sow.

Since skeletal muscles are generally composed of different fibers demonstrating various biochemical, histochemical and physiological properties, we wished to determine whether early lactation in sows induced specific changes in the biochemical and histochemical properties of the main populations of fibers.

The objective of the present study therefore was to investigate the changes in some biochemical and histochemical characteristics of muscles of different contractile and metabolic types during early lactation in primiparous sows.

\section{MATERIALS AND METHODS}

\section{Animals}

During pregnancy 12 Large White primiparous sows were fed $2.2 \mathrm{~kg} / \mathrm{d}$ of a standard diet con- taining $13 \%$ crude protein and $3000 \mathrm{kcal} \mathrm{ME/}$ kg. After farrowing, they received a diet containing $14.6 \%$ crude protein and $3200 \mathrm{kcal} \mathrm{ME} / \mathrm{kg}$. The feeding level was progressively increased from 2 to $5 \mathrm{~kg} / \mathrm{d}$ between $\mathrm{d} 0$ and 5 post-partum, and was then maintained at $5 \mathrm{~kg} / \mathrm{d}$ until weaning at $21 \mathrm{~d}$. The sows were fed twice daily and water was available ad libitum. Mean energy intake over the $21 \mathrm{~d}$ of lactation was $14.8 \mathrm{Mcal} \mathrm{ME} / \mathrm{d}$. The daily supply of nutrients (protein, amino acids, vitamins and minerals) met or exceeded INRA recommendations (1984). The composition and characteristics of the diets were defined previously (Noblet and Etienne, 1986). Litter size was standardized to 10 piglets on the day following farrowing. The piglets did not receive any feed or water supplement from birth to 3 weeks of age.

The weight of the sow and the litter was recorded on the days of farrowing $\left(D_{0}\right)$ and weaning $\left(D_{+21}\right)$; backfat thickness of the sows was ultrasonically determined at shoulder and last rib levels, $50 \mathrm{~mm}$ from the mid-line, on each side of the back. Backfat measurements were averaged within and between sites.

\section{Muscle measurements}

\section{Muscle biopsy}

A general anaesthesia, starting with an iv injection of pentothal, was maintained for $20 \mathrm{~min}$ through inhalation of a mixture of halothane and oxygen. Biopsies of the longissimus dorsi (LD), a glycolytic muscle, and of the trapezius $(T)$, an oxidative muscle, were performed $6 \mathrm{~d}$ before farrowing $\left(D_{-6}\right)$ on the left side and after $21 \mathrm{~d}$ of lactation $\left(D_{+21}\right)$ on the right side. Muscle samples weighing about $1 \mathrm{~g}$ were obtained via an incision of the skin and subcutaneous adipose tissue. The biopsy was kept on flat sticks, promptly frozen in isopentane cooled by liquid nitrogen $\left(-160^{\circ} \mathrm{C}\right)$ and stored at $-80^{\circ} \mathrm{C}$ until metabolic enzyme analysis and histological examination.

\section{Muscle cellularity}

DNA concentration was measured fluorometrically using Hoescht 33258 according to West et al (1985). The method, developed for cultured 
mammalian cells, was adapted to $40 \mu \mathrm{m}$ thick muscle slices.

\section{Histological examination}

Ten- $\mu \mathrm{m}$ thick muscle sections were obtained with a cryostat at $-20^{\circ} \mathrm{C}$. They were processed according to the myosin ATPase technique fol-

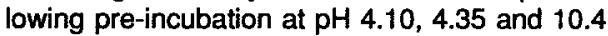
(Padykula and Herman, 1955; Guth and Samaha, 1969). Myofibers were classified as type I, IIA and IIB according to the terminology of Brooke and Kaiser (1970). Type IIC fibers were not considered because very few of them could be observed at this stage of development (Suzuki and Cassens, 1980). For each sample, percentages of the 3 types were determined on about 1500 fibers, and mean cross sectional areas were estimated by planimetry on at least 100 fibers of each type.

\section{Enzyme analysis}

Metabolic enzyme activities were measured from frozen tissue. Muscle tissue was thawed and homogenized in ice-chilled $.1 \mathrm{mo} / / \mathrm{phos}-$ phate buffer ( $\mathrm{pH} 7.5$ ) containing $2 \mathrm{mmol} / \mathrm{l}$ EDTA. The homogenate was centrifuged $(1500 \mathrm{~g}$ for 10 min at $4^{\circ} \mathrm{C}$ ) and the supernatant collected to measure the following enzyme activities: citrate synthase (CS) (Srere, 1969), isocitrate dehydrogenase (ICDH) (Bernt and Bergmeyer, 1974), 3-hydroxy-acyl-CoA dehydrogenase (HAD) and lactate deshydrogenase (LDH) (Bass et al, 1969) in order to characterize the citric acid cycle activity (CS and ICDH), lipid oxidation (HAD) and glycolytic capacity (LDH). Enzyme activities were determined at $30^{\circ} \mathrm{C}$ using spectrophotometric techniques and expressed as mmol (substrate degraded) $\cdot \mathrm{min}^{-1} \cdot \mathrm{g}^{-1}$ (fresh tissue).

\section{Statistical analysis}

Differences between means were tested for statistical significance by the $t$-test for paired observations, each sow being its own control (Snedecor and Cochran, 1957).

\section{RESULTS AND DISCUSSION}

\section{Growth performance}

All sows nursed 10 piglets from farrowing to weaning $3 \mathrm{wk}$ later. No health problem was noted during the experimental period. During the $3 \mathrm{wk}$ of lactation, the average daily feed intake of the sows was $4.6 \pm 0.4$ $\mathrm{kg}$; litter weight gain was $40.1 \pm 4.7 \mathrm{~kg}$ and the sows lost $19.7 \pm 6.6 \mathrm{~kg}$ of body weight $(P<0.001)$, ie $10 \%$ of their initial body weight $(198 \mathrm{~kg})$. A $2.9 \mathrm{~mm}$ decrease $(P<$ 0.001 ) in dorsal fat thickness was observed, indicating fat mobilization. Using the equations calculated by Etienne et al (1989), muscle loss was estimated as 11.1 $\mathrm{kg}$ in the present experiment. These results are equivalent to those reported by Etienne et al (1985) in primiparous sows maintained in similar experimental conditions.

\section{Muscle DNA concentration}

No change in the DNA concentration of either muscle was observed during lactation. DNA concentrations were $0.35 \pm 0.02$ and $0.34 \pm 0.03 \mathrm{mg} / \mathrm{g}$ of fresh muscle in LD muscle and $0.76 \pm 0.09$ and $0.75 \pm 0.18$ in T muscle $6 \mathrm{~d}$ before farrowing and after 21 d of lactation, respectively. These values are in the same range as in muscles of pigs of $100 \mathrm{~kg}$ live weight (Powell and Aberle, 1975; Harbison et al, 1976). The higher concentration of DNA in T than in LD accords with previous results obtained in laboratory animals (Schmalbruch and Hellhammer, 1977). Because skeletal muscle fibers are multinucleated, DNA concentration should not be equated with muscle fiber number but be considered as an esti- 
mate of the cytoplasmic volume associated with each nucleus. Thus, the size of the nucleoplasmic units was not modified during lactation. In consequence, if we assume that muscle weight decreases during lactation (Etienne et al, 1985), this suggests that the amount of muscular DNA decreased during lactation. Taking into account Moss' results (1968) showing the constancy of the ratio between the number of nuclei and the mean cross sectional area of myofibers, a decrease in the latter could be predicted; this is reported later on. The absence of change in LD muscle DNA concentration during lactation, whereas the fiber cross sectional area decreased, shows that DNA concentration is not a good estimate of muscle fiber size.

\section{Percentages of muscle fibers of each type}

In this study, we have selected 2 skeletal muscles presenting various contractile and metabolic characteristics. The proportions of type I, IIA and IIB fibers were 11.7, 10.0, 78.3 and $59.2,21.9,18.9$ in LD and T muscle, respectively. No significant change was noticed in trapezius, whereas the percentage of type $\mathrm{I}$ increased $(P<0.05)$ in LD muscle during lactation (fig 1). Since the total number ot muscle fibers is determined before birth in pigs (Staun, 1963; Stickland and Goldspink, 1973), the increase in the proportion of type I fibers in longissimus was generated by a transformation of fibers from type IIA, or type IIB

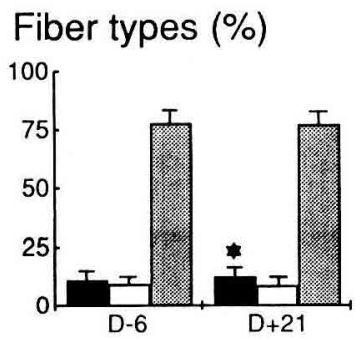

\section{LONGISSIMUS MUSCLE}
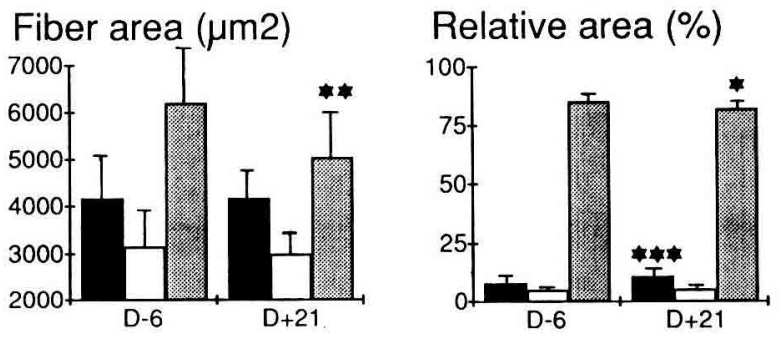

\section{TRAPEZIUS MUSCLE}
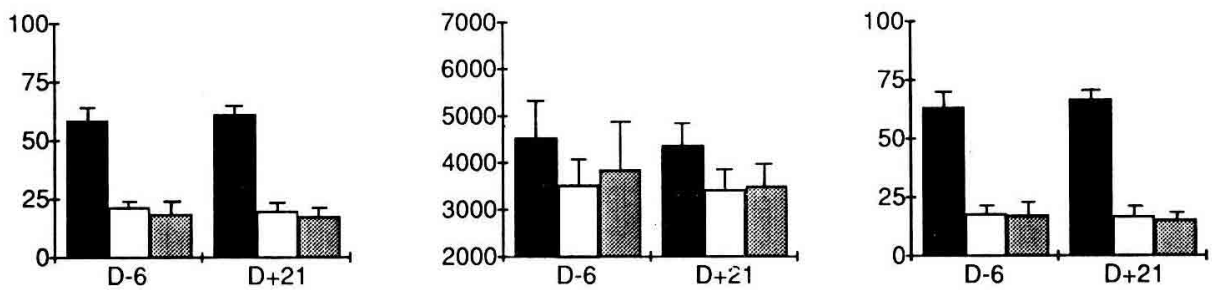

Fig 1. Changes in muscle histological characteristics between $6 \mathrm{~d}$ before farrowing $\left(D_{-6}\right)$ and the $21 \mathrm{st}$ $\mathrm{d}$ of lactation $\left(\mathrm{D}_{+21}\right)$ in the primiparous sow. Type I $\mathbf{m}$, type IIA $\square$ and type IIB fibers (Brooke and Kaiser, 1970). The mean values are indicated with the SEM. Compared with $D_{-6}:{ }^{*}, P<0.05 ;{ }^{* *}, P<$ $0.01 ;{ }^{* * *}, P<0.001$. 
via IIA, to type I fibers. This effect is similar to that observed in fast muscles after hypothyroidism in laboratory animals (Nwoye and Mommaerts, 1981). The lower concentrations of serum $T_{4}$ during lactation as compared to gestation in the primiparous sow (Brendemuhl et al, 1987) might explain the increase in type 1 fibers in LD muscle, but direct evidence is still lacking. Moreover, other studies are necessary to establish whether the lower $\mathrm{T}_{4}$ concentration observed during lactation was due to a decrease in secretion and/or to an increase in peripheric utilization, ie tissues and milk. Thus, a real hypothyroidal status during lactation is still hypothetical and should be studied at a muscular level.

\section{Muscle fiber area}

Muscle fiber cross sectional areas (CSA) were not significantly affected by lactation, with the exception of type IIB fibers in LD muscle $(P<0.01$; fig 1 ). Reid et al (1980) previously reported a decrease in mean fiber diameter in $T$ muscle of early lactating cows. However, they only studied T muscle and did not take into account fiber types. In the sow, the LD, a white muscle, seemed to be more sensitive to the atrophic action of lactation, and within this muscle, mainly the type IIB fibers (about $78 \%$ of the total number of fibers) were affected. Since the total number of muscle fibers did not change, the decrease in fiber cross sectional areas in LD muscle (- 18.2\%) suggests a decrease in the weight of this muscle. Muscles may be affected contrary to their development since LD muscle, a late developing muscle, is more affected than $\mathrm{T}$, an earlier developing muscle (Davies, 1974; Dickerson and McCance, 1960).

These changes are very similar to those observed in laboratory animals after a peri- od of starvation, restricted feeding or glucocorticoid treatment that induces a decrease in the size of fast twitch fibers, particularly glycolytic fibers, while slow-twitch fibers are much more resistant to atrophy (Goldberg and Goodman, 1969; Vignos and Greene, 1973; Kelly and Goldspink, 1982; Seene and Viru, 1982; Kelly et al, 1986). Activity and/or hormone responsiveness could generate the difference in response between muscles. Within a muscle, the activation threshold increases from type I to IIA and IIB fibers (Henneman et al, 1974; Vollestad and Blom, 1985). The continuous activity of $T$ muscle in the maintenance of body posture and in movements of a slow, repetitive nature, may make this muscle somewhat resistant to atrophy. In contrast, the longissimus muscle, a fast-twitch glycolytic muscle, is less frequently recruited and is clearly more susceptible to atrophy.

The higher resistance of $T$ muscle to atrophy may also be due to its more intense metabolism since it has been shown in laboratory animals that RNA concentration and protein synthesis (Flaim et al, 1980), protein turnover (Lewis et al, 1984), incorporation of glucose into glycogen (Bar and Blanchaer, 1965; Beatty and Bocek, 1970), turnover of glycogen (Villa-Moruzzi et al, 1979), insulin receptor concentration (Lefaucheur et al, 1986) and the sensitivity of glucose uptake to insulin (Bonen et al, 1981; Hom and Goodner, 1984) are higher in slow red than in fast white muscles.

Insulin and glucocorticoids might be involved in the higher sensitivity of IIB fibers to atrophy. Indeed, insulin is known to stimulate protein synthesis and inhibit protein degradation in muscle (Goldberg, 1979; Tischler, 1981; Etherton, 1982), and it may be that the lower number of insulin recertors in fast white fibers (Lefaucheur et al, 1986) makes them more sensitive to the reduction of plasma insulin level occur- 
ring after farrowing (Atinmo et al, 1976; Armstrong et al, 1986). It has been shown that the catabolism induced by starvation is triggered, at least in part, by glucocorticoids (Goldberg et al, 1980) and that $11 \mathrm{~B}$ fibers are more susceptible to the atrophying action of glucocorticoids than I and IIA fibers (Kelly et al, 1986). Nevertheless, other hormonal changes occur during early lactation vs gestation. For instance, higher growth hormone levels have been demonstrated in dairy cows during early lactation (Kunz et al, 1985) but this hormone is probably not involved in mechanisms leading to fiber hypotrophy; it would rather contribute, like hypothyroidism, to spare muscular proteins. Further investigations are needed to understand the hormonal mechanisms involved.

\section{Enzyme activities}

Oxidative (CS, ICDH, HAD) and glycolytic $(\mathrm{LDH})$ enzyme activities decreased in LD and $T$ muscles during lactation (fig 2); oxidative activities were particularly reduced in the red $\mathrm{T}$ muscle. Thus, in the lactating sow, energy and protein deficits (Etienne et al, 1989) seem to be related to a general decrease in both muscular oxidative and glycolytic metabolisms. Energy and/or protein restriction also induce a decline in oxidative metabolism in rats, sheep and monkeys (Taskar and Tulpule, 1964; Goldspink and Waterson, 1971; Howarth and Baldwin, 1971; Suzuki, 1972; Oldfors et al, 1983; Mehta et al, 1987) but do not modify or even increase glycolytic enzyme activities in the muscle of rats and rhesus mon-
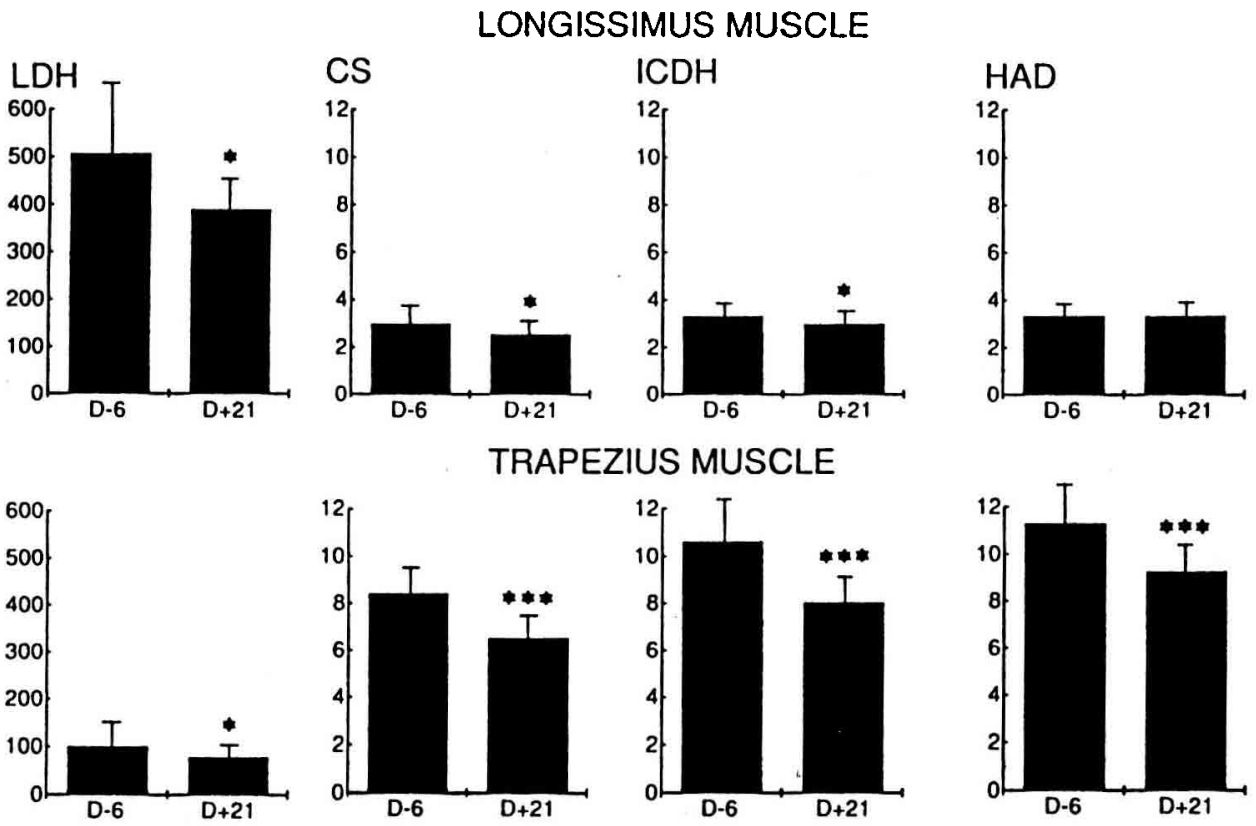

Fig 2. Changes in muscle enzyme activities between $6 \mathrm{~d}$ before farrowing $\left(D_{-6}\right)$ and the $21 \mathrm{st} \mathrm{d}$ of lactation $\left(D_{+21}\right)$ in the primiparous sow. LDH: lactate dehydrogenase; CS: citrate synthase; ICDH: isocitrate dehydrogenase; HAD: beta-hydroxyacyl coenzyme-A dehydrogenase. The mean values are indicated with SEM. Compared with $D_{-6}:{ }^{*}, P<0.05 ; " *, P<0.01 ; " * *, P<0.001$. 
keys (Taskar and Tulpule, 1964; Mehta et al, 1987). If muscle metabolic response to starvation or feed restriction is similar in swine and in these species, lactation and a low plane of nutrition could distinctly affect glycolytic metabolism.

A general reduction in muscular glycolytic and oxidative metabolisms has already been reported in hypothyroidism in laboratory animals (Johnson and Turnbull, 1984). Since $T_{4}$ is decreased during lactation in the sow (Brendemuhl et al, 1987), it might be involved in the overall reduction in muscle energy metabolism during early lactation via a decrease in $T_{4}$ uptake by muscle.

\section{CONCLUSION}

The present study shows that histochemical and biochemical changes occur in muscle of primiparous sows during lactation. It appears that IIB fibers, mainly of the glycolytic type, are selectively affected during early lactation when food intake does not meet nutrient demand for milk production. As the musculature represents about $40 \%$ of the body mass after farrowing and is predominantly made up of fast glycolytic muscles, the fast glycolytic skeletal muscles probably constitute a substantial part of the labile protein reserve. The observed reduction in muscle energy metabolism, characterized by a decrease in oxidative and glycolytic enzyme activities, and the increase of type 1 fibers of LD muscle could be related to a reduction in thyroxine levels in sows during late gestation and lactation. However, further research is needed to demonstrate this hypothesis.

\section{ACKNOWLEDGMENTS}

The authors wish to thank $Y$ Lebreton for technical assistance in surgical interventions.

\section{REFERENCES}

Armstrong JD, Britt JH, Kraeling RR (1986) Effect of restriction of energy during lactation on body condition, energy metabolism, endocrine changes and reproductive performance in primiparous sows. J Anim Sci 63, 19151925

Atinmo T, Baldijao C. Pond WG. Barnes RH (1976) Decreased dietary protein on energy intake and plasma growth hormone levels of the pregnant pig, its fetuses and developing progeny. J Nutr 106, 940-946

Bar U, Blanchaer MC (1965) Glycogen and $\mathrm{CO}_{2}$ production from glucose and lactate by red and white skeletal muscle. Am J Physiol 209, 905-909

Bass A, Brdiczka D, Eyer P, Pette D (1969) Metabolic differentiation of distinct muscle types at the level of enzymatic organization. Eur J Biochem 10, 198-206

Beatty $\mathrm{CH}$, Bocek RM (1970) Biochemistry of the red and white muscle. In: Physiology and Biochemistry of Muscle as a Food (Briskey EJ, Cassens RG, Marsh RG, eds) King-sport Press, Tennessee, 155-191

Bernt E, Bergmeyer HU (1974) Isocitrate dehydrogenase: UV-assay. In: Methods of Enzymatic Analysis (Bergmeyer HU, ed) Academic Press, New York 2, 624-627

Bonen A, Tan MN, Watson-Wright WM (1981) Insulin binding and glucose uptake differences in rodent skeletal muscles. Diabetes 30 , 702-704

Brendemuhl JH, Lewis AJ, Peo ER (1987) Effect of protein and energy intake by primiparous sows during lactation on sow and litter performance and sow serum thyroxine and urea concentrations. J Anim Sci 64, 1060-1069

Brooke MH, Kaiser KK (1970) Muscle fiber types: How many and what kind? Arch Neurol 23, 369-379

Davies AS (1974) A comparison of tissue development in Pietrain and Large White pigs from birth to $64 \mathrm{~kg}$ live weight. 2. Growth changes in muscle distribution. Anim Prod 19, 377387

Dickerson JWT, McCance RA (1960) Severe undernutrition in growing and adult animals: avian skeletal muscle. Br J Nutr 14, 331-338 
Elsley FWH, MacPherson RM (1972) Protein and amino acid requirements in pregnancy and lactation. In: Pig Production (Cole DJA, ed) The Pennsylvania State Univ Press, University Park, 417-434

Etherton TD (1982) The role of insulin-receptor interactions in regulation of nutrient utilization by skeletal muscle and adipose tissue: a review. J Anim Sci 54, 58-67

Etienne M, Noblet J, Desmoulin B (1985) Mobilisation des réserves corporelles chez la truie primipare en lactation. Reprod Nutr Dev 25, 341-344

Etienne M, Noblet J, Dourmad JY, Fortune H (1989) Etude du besoin en lysine des truies en lactation. J Rech Porcine Fr 21, 101-108

Flaim KE, Copenhaver ME, Jefferson LS (1980) Effects of diabetes on protein synthesis in fast and slow twitch rat skeletal muscle. Am J Physio/ 239, E88-E95

Goldberg AL (1979) Influences of insulin and contractile activity on muscle size and protein balance. Diabetes 28, 18-24

Goldberg AL, Goodman HM (1969) Relationship between cortisone and muscle work in determining body size. J Physiol (Lond) 200, 667. 675

Goldberg AL, Tischler M, Demartino G, Griffin G (1980) Hormonal regulation of protein degradation and synthesis in skeletal muscle. Fed Proc 39, 31-36

Goldspink G, Waterson SE (1971) The effect of growth and inanition on the total amount of nitroblue tetrazolium deposited in individual muscle fibers of fast and slow rat skeletal muscle. Acta Histochem 40, 16-22

Guth L, Samaha FJ (1969) Qualitative differences between actomyosin ATpase of slow and fast mammalian muscle. Exp Neurol 25, 138152

Harbison SA, Goll DE, Parrish FC, Wang V, Kline EA (1976) Muscle growth in two genetically different lines of swine. Growth $40,253-$ 283

Henneman E, Clamann HP, Gilles JD, Skinner RD (1974) Rank order of moloneurones within a pool: law of combination. J Neurophysiol (Bethesda) 37, 1338-1349

Hom FG, Goodner CJ (1984) Insulin doseresponse characteristics among individual muscle and adipose tissues measured in the rat in vivo with ${ }^{3}(\mathrm{H})$-2-deoxyglucose. Diabetes $33,153-160$

Howarth RE, Baldwin RL (1971) Concentrations of selected enzymes and metabolites in rat skeletal muscle: effects of food restriction. $J$ Nutr 101, 485-494

INRA (1984) L'alimentation des animaux monogastriques : porc, lapin volailles. INRA, Paris

Johnson MA, Turnbull DM (1984) Mitochondrial oxidative enzyme activity in individual fiber types in hypo and hyperthyroid rat skeletal muscles. J Exp Physiol 69, 257-270

Kelly FJ, Goldspink DF (1982) The differing responses of four muscle types to dexamethasone treatment in the rat. Biochem $J 208$, 147-151

Kelly FJ, McGrath JA, Goldspink DF, Cullen MJ (1986) A morphological and biochemical study on the actions of corticosteroids on rat skeletal muscle. Muscle Nerve 9, 1-10

Kunz PL, Blum JW, Hart IC, Bickel $H$, Landis J (1985) Effects of different energy intakes before and after calving on food intake, performance and blood hormones and metabolites in dairy cows. Anim Prod 40, 219-231

Lefaucheur L, Le Peuch C, Barenton B, Vigneron $P$ (1986) Characterization of insulin binding to slices of slow and fast twitch skeletal muscles in the rabbit. Horm Metab Res 18, 725-729

Lewis EM, Kelly FJ, Goldspink DF (1984) Pre and postnatal growth and protein turnover of smooth muscle, heart and slow and fast twich skeletal muscles of the rat. Biochem $J$ 217, 517-526

Mehta J, Chopra JS, Mehta S, Naim CK, Bhagwat AG, Dhand UK, Rana SV (1987) Ultrastructure and activity of some enzymes of energy metabolism of skeletal muscle in experimental energy deficiency. Ann Nutr \& Metab 31, 35-46

Moss FP (1968) The relationship between the dimensions of the fibers and the number of nuclei during normal growth of skeletal muscle in the domestic fowl. Am J Anat 122, 555564

Noblet J. Etienne M (1986) Effect of energy level in lactating sows on yield and composition of milk and nutrient balance of piglets. J Anim Sci 63, 1888-1896 
Nwoye L, Mommaerts WFHM (1981) The effect of thyroid status on some properties of rat fast twitch muscle. J Muscle Res Cell Motil 2, 307-320

Oldfors A, Mair WGP, Sourander P (1983) Muscle changes in protein-deprived young rats. $A$ morphometrical, histochemical and ultrastructural study. J Neurol Sci 59, 291-302

Padykula HA, Herman E (1955) Factors affecting the activity of adenosine triphosphatases as measured by histochemical techniques. $J$ Histochem Cytochem 3, 161-169

Powell SE, Aberle ED (1975) Cellular growth of skeletal muscle in swine differing in muscularity. J Anim Sci 40, 476-485

Reid IM, Roberts CJ, Baird GD (1980) The effects of underfeeding during pregnancy and lactation on structure and chemistry of bovine liver and muscle. J Agric Sci Camb 94, 239245

Schmalbruch $H$, Hellhammer $U$ (1977) The number of nuclei in adult rat muscles with special reference to satellite cells. Anat Rec 189, 169-176

Seene TP, Viru AA (1982) The catabolic effect of glucocorticoids on different types of skeletal muscle fibers and its dependence upon muscle activity and interaction with anabolic steroids. J Steroid Biochem 16, 349-352

Snedecor GW, Cochran WG (1957) Statistical Methods, 6th ed, lowa State Univ Press Ames, lowa, USA

Srere PA (1969) Citrate synthase. Methods Enzymol 13, 3-5

Staun $H$ (1963) Various factors affecting number and size of muscle fibers in the pig. Acta Agr Scand 13, 292-322
Stickland NC, Goldspink G (1973) A possible indicator for the fiber content and growth characteristics of porcine muscle. Anim Prod 16, 135-146

Suzuki A (1972) Histochemical observations of individual skeletal muscle fibers in starved sheep. Jpn J Zootech Sci 44, 50-58

Suzuki A, Cassens RG (1980) A histochemical study of myofiber types in muscle of the growing pig. J Anim Sci 51, 1449-1461

Taskar K, Tulpule PG (1964) Influence of protein and caloric deficiencies in the rat on the energy-transfer reactions of the striated muscle. Biochem J 92, 391-398

Tischler ME (1981) Hormonal regulation of protein degradation in skeletal and cardiac muscle. Life Sci 28, 2569-2576

Vignos PJ, Greene R (1973) Oxidative respiration of skeletal muscle in experimental corticosteroid myopathy. J Lab Clin Med 81, 365378

Villa-Moruzzi E, Locci-Cubeddu T, Bergamini E (1979) Developmental changes of glycogen enzymes in fast and slow muscles of the rat. Growth 43, 73-79

Vollestad NK, Blom PCS (1985) Effect of varying exercise intensity on glycogen depletion in human muscle fibers. Acta Physiol Scand $125,395-405$

West DC, Sattar A, Kumar S (1985) A simplified in situ solubilization procedure for the determination of DNA and cell number in tissue cultured mammalian cells. Anal Biochem $147,289-295$

Whittemore CT, Franklin MF, Pearce BS (1980) Fat changes in breeding sows. Anim Prod 31, 183-190 